\title{
Mind the headache: rare bilateral cerebellar infarction in a young female patient
}

\author{
Cheuk Tung Kam 이 , ${ }^{1}$ Jaideep Singh Rait ${ }^{2}$
}

${ }^{1}$ Acute Internal Medicine, Maidstone and Tunbridge Wells NHS Foundation Trust, Maidstone, UK

${ }^{2}$ General Surgery, Maidstone and Tunbridge Wells NHS Foundation Trust, Tunbridge Wells, UK

\section{Correspondence to}

Dr Cheuk Tung Kam; cheuk.kam@nhs.net

Accepted 30 May 2021

\section{DESCRIPTION}

A 35-year-old female patient presented to the emergency department of a district general hospital with a 5-hour history of sudden onset headache associated with multiple episodes of vomiting. Her medical history included migraine with aura and she was on no regular medication. Admission examination findings were normal with no focal neurological deficits, dysarthria, or ataxia, neither stance/ gait nor limbs. Biochemistry and haematology were unremarkable with no signs of infection.

A CT was initially performed to rule out subarachnoid haemorrhage, which showed no acute intracranial pathology (figure 1A). Lumbar puncture was negative on xanthochromia screen with negative viral screen for hepatitis, syphilis, Cytomegalovirus (CMV), Human Immunodeficiency Virus (HIV) and Epstein-Barr virus (EBV). MRI was later undertaken which demonstrated multiple large bilateral cerebellar infarcts involving multiple cerebellar territories (figure 1B) with normal magnetic resonance arteriography (figure 2).

Following this a stroke team referral was completed and she developed cerebellar signs (staccato dysarthria, ataxia, dysmetria, cerebellar rebound and dysdiadochokinesia) as time progressed. CT angiogram of the aortic arch and carotids showed no vertebral artery dissection. Bubble contrast echo did not show a patent foramen ovale. Her case was treated as idiopathic cerebellar stroke and for further rehabilitation in the community.
Migraine is associated with increased risk for stroke by twofold. ${ }^{1}$ Multiple studies have demonstrated their association. ${ }^{1}$ Several factors have been explored with no clear aetiology of stroke in those with migraine. Possible stroke mimics include migraine with aura which is at times challenging in the evaluation of potential ischaemic stroke in young women, particularly cerebellar origin. The literature has shown a large proportion of young patients with cerebellar infarctions at initial presentation have been misdiagnosed. ${ }^{2}$

Cerebellar infarcts are rare in young adults, and extremely rare with bilateral and multiple cerebellar territories involvement. ${ }^{3}$ Under the age of 35 , the rates of cerebellar infarcts in general are only $0.002 \%$ per year. ${ }^{45}$ Early diagnosis remains a challenge due to lack of awareness and the relative rarity of stroke compared with other commoner pathology. The diagnostic yield and the cost associated are highly variable between the tests. Appropriate guidelines and strategies should be devised to evaluate stroke in the younger population.

Common risk factors include those for vascular disease. $^{6}$ Symptoms such as dizziness or nausea arising from changes in posture particularly walking are more suspicious for cerebellar infarcts. ${ }^{6}$ Headache should also be evaluated if the pattern does not follow any primary headache syndromes, accompanied by abnormal neurological examination, is progressive, or is of acute onset. ${ }^{7}$ The presence of ataxia, diplopia, nystagmus or dysarthria should increase the concern for cerebellar infarcts. ${ }^{6}$
A Check for updates

(c) BMJ Publishing Group Limited 2021. No commercial re-use. See rights and permissions. Published by BMJ.

To cite: Kam CT, Rait JS. BMJ Case Rep 2021;14:e244161. doi:10.1136/bcr-2021244161

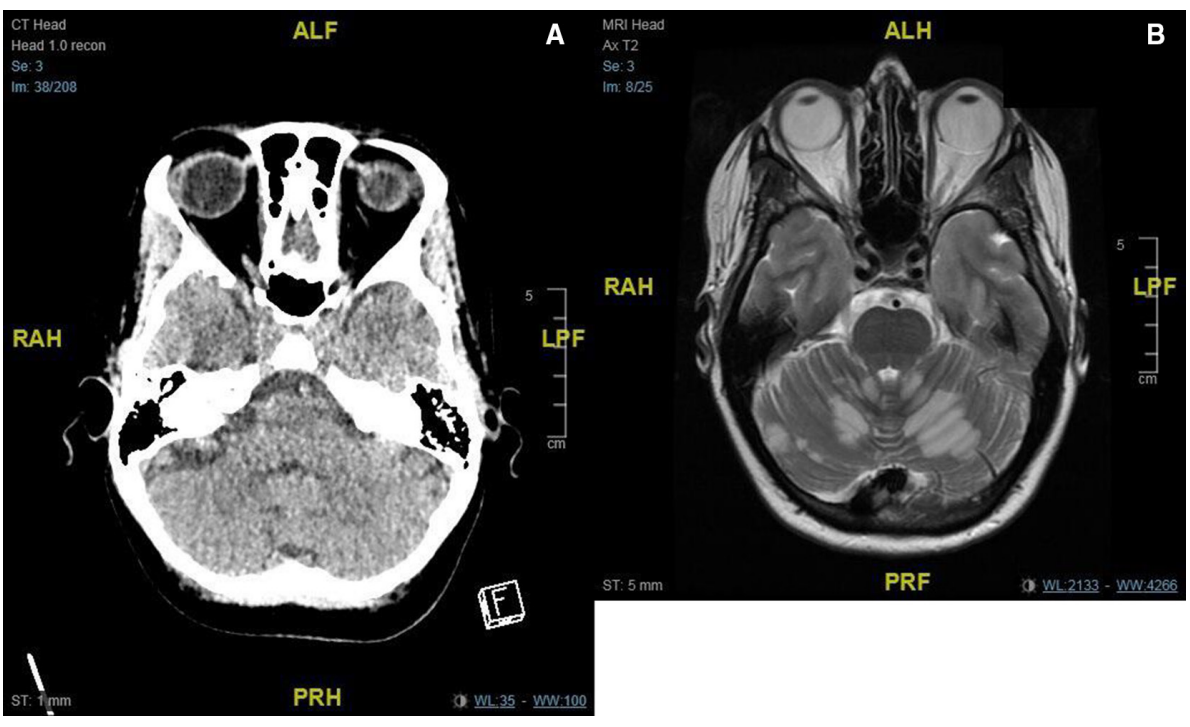

Figure 1 (A) Normal CT head image showing no acute intracranial pathology. (B) MRI image showed multiple large areas of restricted diffusion bilaterally within the cerebellar hemispheres consistent with acute cerebellar infarction. 


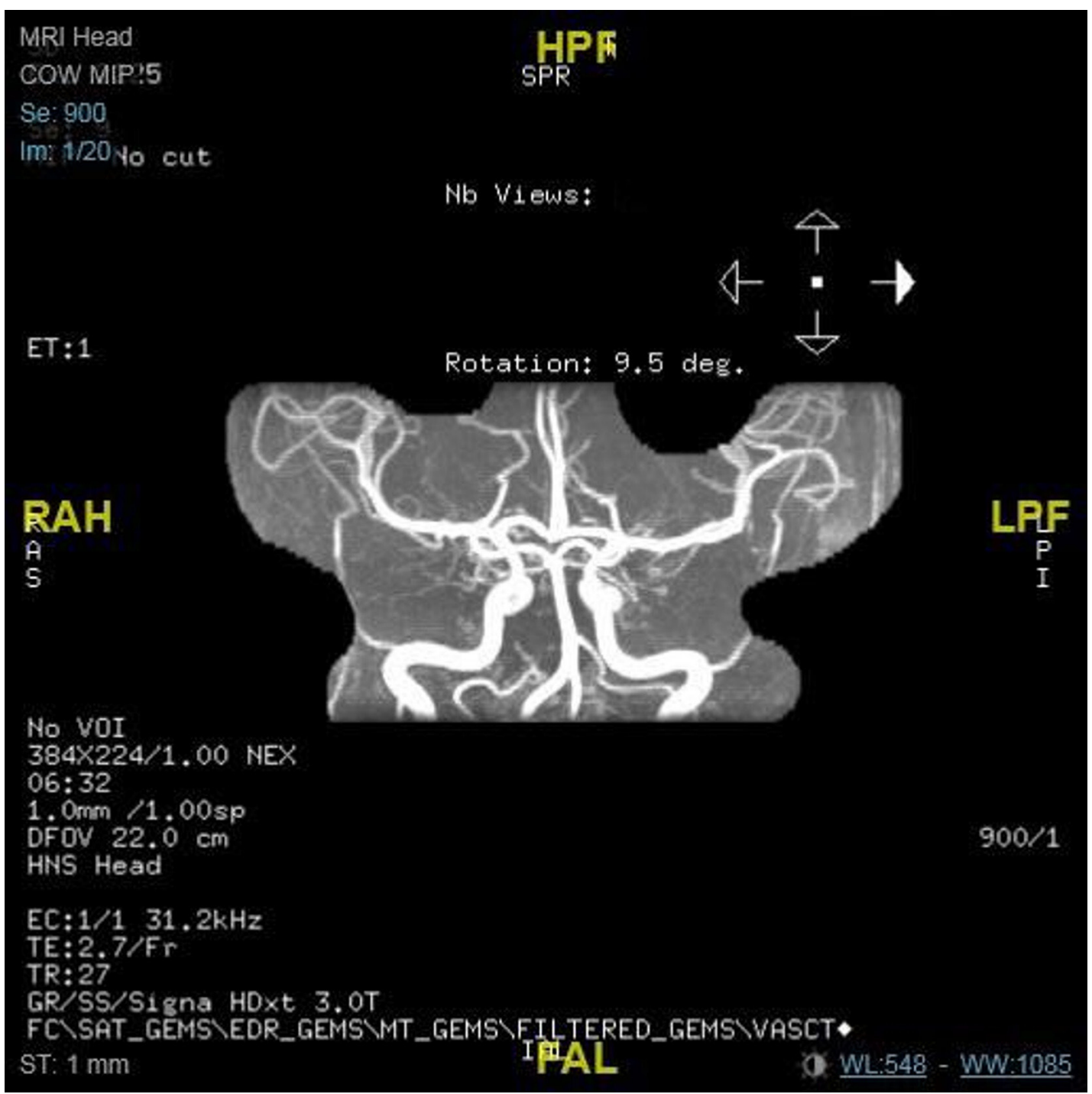

Figure 2 Magnetic resonance arteriography demonstrated normal appearances of intracranial arteries and basilar artery.

Although cerebellar infarcts happen rarely, it has a major impact on the individual and society. Stroke in a young person can be devastating in terms of productive years lost and impact on quality of life. Clinicians should conduct thorough neurological examinations, have a greater awareness, and knowledge of appropriate brain imaging to improve diagnosis of cerebellar stroke. A multidisciplinary approach is essential in improving care and outcomes of stroke in young adults.

\section{Learning points}

- Stroke can mimic migraine which also increases the risks of ischaemic stroke in young adults.

- Different approach to investigations and management is required for young patients as the possible underlying causes are different.

- Greater awareness of cerebellar stroke symptoms, and knowledge of appropriate brain imaging helps diagnosing and managing cerebellar stroke early.
Contributors CTK contributed to the writing of the manuscript and design. JSR reviewed the final version.

Funding The authors have not declared a specific grant for this research from any funding agency in the public, commercial or not-for-profit sectors.

Competing interests None declared.

Patient consent for publication Obtained.

Provenance and peer review Not commissioned; externally peer reviewed.

ORCID iD

Cheuk Tung Kam http://orcid.org/0000-0002-2026-6047

\section{REFERENCES}

1 Schürks M, Rist PM, Bigal ME, et al. Migraine and cardiovascular disease: systematic review and meta-analysis. BMJ 2009;339:b3914-b3914:b3914.

2 Chang BP, Wira C, Miller J, et al. Neurology concepts: young women and ischemic Stroke-Evaluation and management in the emergency department. Acad Emerg Med 2018;25:54-64.

3 Gurer G, Sahin G, Cekirge S, et al. Acute bilateral cerebellar infarction in the territory of the medial branches of posterior inferior cerebellar arteries. Clin Neurol Neurosurg 2001;103:194-6

4 Griffiths D, Sturm J. Epidemiology and etiology of young stroke. Stroke Res Treat 2011:2011:1-9.

5 Macdonell RA, Kalnins RM, Donnan GA. Cerebellar infarction: natural history, prognosis, and pathology. Stroke 1987;18:849-55.

6 Ioannides K, Tadi P, Naqvi I. Cerebellar infarct, 2021.

7 Stern T. Massachusetts General Hospital. London: Elsevier, 2016. 
Copyright 2021 BMJ Publishing Group. All rights reserved. For permission to reuse any of this content visit https://www.bmj.com/company/products-services/rights-and-licensing/permissions/

BMJ Case Report Fellows may re-use this article for personal use and teaching without any further permission.

Become a Fellow of BMJ Case Reports today and you can:

- Submit as many cases as you like

- Enjoy fast sympathetic peer review and rapid publication of accepted articles

- Access all the published articles

Re-use any of the published material for personal use and teaching without further permission

Customer Service

If you have any further queries about your subscription, please contact our customer services team on +44 (0) 2071111105 or via email at support@bmj.com.

Visit casereports.bmj.com for more articles like this and to become a Fellow 